\title{
Konstruksi Kelembagaan Perwakilan Dalam Pelaksanaan Asas Kedaulatan Rakyat
}

\author{
Sherlock Halmes Lekipiouw \\ Fakultas Hukum Universitas Pattimura, Ambon, Indonesia \\ E-mail:halmes_elok@yahoo.com
}

\begin{abstract}
Constitutionalism is not just a matter of dismantling pairs of texts and their institutions through the constitution, but rather as a leap of critical thinking and concrete actions to provide assurance of social welfare rights as basic rights of citizens who cannot be neglected at all by the organizers of power. That is one way to interpret constitutional theory and law to be more substantive, dignified and grounded for all citizens.
\end{abstract}

Keywords: Institutional Construction, Representation, People's Sovereignty.

\section{A. PENDAHULUAN.}

Perdebatan mengenai wacana konstitusi dewasa ini sesungguhnya dipengaruhi pula oleh sejumlah konteks sosial politik di Indonesia pasca Soeharto. Konteks sosial politik sebagai pemantik perdebatan-perdebatan itu adalah proses pergeseran kekuasaan dan ketatanegaraan, perubahan undang - undang dasar, serta desakan publik yang begitu kuat di tengah eforia reformasi. Tentu, perdebatan - perdebatan tersebut menggiring pada disain-disain paradigmatik yang sangat besar mempengaruhi politik hukum perubahan konstitusi. Seiring dengan perubahan tersebut telah banyak melahirkan sejumlah pemikiran - pemikiran baru maupun alternatif terhadap objek studi ketatanegaraa $^{1}$. Basis pokok berlakunya konstitusi adalah adanya kesepakatan umum atau persetujuan (consensus) di antara mayoritas rakyat mengenai bangunan yang diidealkan berkenaan dengan negara. Organisasi negara itu diperlukan oleh warga masyarakat politik agar kepentingan mereka bersama dapat dilindungi atau dipromosikan melalui pembentukan dan penggunaan mekanisme yang disebut negara ${ }^{2}$.

1 Lihat tulisan Ellydar Chaidir, Teori Konstitusi Dalam Prespektif Hukum Kritis, Total Media, Yogyakarta, 2007, Jimly assidiqie, Konstitusi \& Konstitusionalisme Indonesia. Edisi Revisi. Jakarta: Konstitusi Press, 2005. dan Gagasan Kedaulatan Rakyat dalam Konstitusi dan Pelaksanaannya di Indonesia. Jakarta: Ichtiar Baru-van Hoeve, 1994.

2 William G. Andrews, misalnya, dalam bukunya Constitutions and Constitutionalism, $3^{\text {rd }}$ edition, menyatakan: "The members of a political 
Dalam perkembangan kehidupan bernegara, konstitusi menempati posisi yang sangat penting. Pengertian dan materi muatan konstitusi senantiasa berkembang seiring dengan perkembangan peradaban manusia dan organisasi kenegaraan. Dengan meneliti dan mengkaji konstitusi, dapat diketahui prinsip-prinsip dasar kehidupan bersama dan penyelenggaraan negara serta struktur organisasi suatu negara tertentu. Bahkan nilai-nilai konstitusi dapat dikatakan mewakili tingkat peradaban suatu bangsa. Kajian tentang konstitusi semakin penting dalam negara-negara modern saat ini yang pada umumnya menyatakan diri sebagai negara konstitusional, baik demokrasi konstitusional maupun monarki konstitusional. Konstitusi tidak lagi sekedar istilah untuk menyebut suatu dokumen hukum, tetapi menjadi suatu paham tentang prinsip-prinsip dasar penyelenggaraan negara (konstitusionalisme) yang dianut hampir di semua negara, termasuk negara-negara yang tidak memiliki konstitusi sebagai dokumen hukum tertulis serta yang menempatkan supremasi kekuasaan pada parlemen sebagai wujud kedaulatan rakyat

Sebagaimana

Undang-Undang dasar 1945 telah mengalami perubahan-perubahan mendasar sejak dari Perubahan Pertama pada tahun 1999 sampai ke Perubahan Keempat pada tahun 2002. Perubahan perubahan ituj juga meliputi materi yang sangat banyak, sehingga mencakup lebih dari 3 kali lipat jumlah materi muatan asli UUD 1945. Jika naskah asli UUD 1945 berisi 71 butir ketentuan, maka setelah empat kali mengalami perubahan, kini

community have, bu definition, common interests which they seek to promote or protect through the creation and use of the compulsory political mechanisms we call the State”, (New Jersey: Van Nostrand Company, 1968), hal. 9. Lebih lanjut lihat Jimly Assidiqie, Gagasan dasar tetang konstitusi dan Mahkamah Konstitusi, h, 12 jumlah materi muatan UUD 1945 seluruhnya mencakup 199 butir ketentuan. Dengan demikian, dapat dikatakan bahwa meskipun namanya tetap merupakan UUD 1945, tetapi dari sudut isinya UUD 1945 pasca Perubahan Keempat tahun 2002 sekarang ini sudah dapat dikatakan merupakan Konstitusi baru sama sekali dengan nama resmi "Undang-Undang Dasar Negara Republik Indonesia Tahun 1945 (UUD NRI Tahun 1945) ${ }^{3}$. Sehubungan dengan itu penting disadai bahwa sistem ketatanegaraan Indonesia setelah Perubahan Keempat UUD 1945 itu telah mengalami perubahan-perubahan yang sangat mendasar. Perubahan - perubahan itu juga mempengaruhi struktur dan mekanisme structural organ-organ negara Republik Indonesia yang tidak dapat lagi dijelaskan menurut cara berpikir lama. Banyak pokok-pokok pikiran baru yang diadopsikan ke dalam kerangka UUD 1945 itu, diantaranya adalah (a) penegasan dianutnya citademokrasi dan nomokrasi secara sekaligus dan saling melengkapi secara komplamenter; (b) pemisahan kekuasaan dan prinsip "checks and balances' (c) pemurnian sistem pemerintah presidential; dan (d) pengeuatan cita persatuan dan keragaman dalam wadah Negara Kesatuan Republik Indonesia. Hal ini sejalan pula susbtansi konstitusionalisme, dimana tujuan atau cita-cita bersama merupakan falsafah kenegaraan atau staatsidee (cita negara)

3 Undang-Undang Dasar Negara Republik Indonesia Tahun 1945 (UUD NRI Tahun 1945) yang merupakan landasan konstitusional penyelenggaraan negara, dalam waktu relatif singkat (1999-2002), telah mengalami 4 (empat) kali perubahan. Dengan berlakunya amandemen UUD NRI Tahun 1945, telah terjadi perubahan dalam pengelolaan pembangunan, yaitu (1) penguatan kedudukan lembaga legislatif dalam penyusunan Anggaran Pendapatan dan Belanja Negara (APBN); (2) ditiadakannya Garis-garis Besar Haluan Negara (GBHN) sebagai pedoman penyusunan rencana pembangunan Nasional; dan (3) diperkuatnya Otonomi Daerah dan desentralisasi pemerintahan dalam Negara Kesatuan Republik Indonesia. 
yang berfungsi sebagai filosofische grondslag atau common platforms atau kalimatun sawa di antara sesama warga masyarakat dalam konteks kehidupan bernegara.

Dasar filsosofis di Indonesia adalah Pancasila serta perwujudan empat tujuan atau cita-cita ideal bernegara yang disebutkan dalam alinea ke-4 Pembukaan UUD 1945. Ketiga kesepakatan tersebut melengkapi inti yang menyangkut prinsip pengaturan dan pembatasan kekuasaan, yaitu: (i) the general goals of society or general acceptance of the same philosophy of government (kesepakatan tentang tujuan atau cita-cita bersama tentang pemerintahan); (ii) the rule of law or the basis of government (kesepakatan tentang negara hukum sebagai landasan pemerintahan atau penyelenggara negara); (iii) the form of institutions and procedures (kesepakatan tentang bentuk institusi-institusi dan prosedur-prosedur ketatanegaraan). Setelah berhasil melakukan perubahan konstitusional, tahapan selanjutnya yang harus dilakukan adalah pelaksanaan UUD 1945 yang telah diubah tersebut. Pelaksanaan UUD 1945 harus dilakukan mulai dari konsolidasi norma hukum hingga dalam praktik kehidupan berbangsa dan bernegara. Sebagai hukum dasar, UUD 1945 harus menjadi acuan dasar sehingga benar-benar hidup dan berkembang dalam penyelenggaraan negara dan kehidupan warga negara (the living constitution).

\section{B. PEMBAHASAN}

\section{MRP RI Pasca Perubahan UUD NRI Tahun 1945}

Semula Majelis Permusyawaratan Rakyat (MPR) dirancang untuk diubah menjadi nama 'genus' dari lembaga perwakilan rakyat atau parlemen Indonesia yang terdiri atas dua kamar dewan. Kamar pertama disebut "Dewan Perwakilan Rakyat (DPR)", dan kamar kedua disebut "Dewan Perwakilan Daerah (DPD)" " . Namun demikian, setelah perubahan Keempat UUD NRI Tahun 1945, keberadaan MPR yang selama ini disebut sebagai lembaga tertinggi negara itu memang telah mengalami perubahan yang sangat mendasar, akan tetapi keberadaannya tetap ada sehingga sistem yang kita anut tidak dapat disebut sistem bikameral ataupun satu kamar, melainkan sistem tiga kamar (trikameralisme).

Sehubungan dengan itu penting disadai bahwa sistem ketatanegaraan Indonesia setelah Perubahan Keempat UUD NRI Tahun 1945 itu telah mengalami perubahan-perubahan yang sangat mendasar. Perubahan-perubahan itu juga mempengaruhi struktur dan mekanisme struktural organ-organ negara Republik Indonesia yang tidak dapat lagi dijelaskan menurut cara berpikir lama 5 .

4 Sebagai perbandingan, prinsip yang sama dapat kita temukan dalam konstitusi Amerika Serikat yang mementukan bahwa semua kekuasaan legislatif ada di Kongres yang terdiri atas 'The House of Representatives and Senate'. Memang, anggota senat bisa disebut Senator sedangkan anggota Dewan Perwakilan Rakyat atau 'House of Representatives' biasa disebut 'Congressman'. Akan tetapi, sesungguhnya, baik anggota Senat maupun anggota DPR Amerika Serikat itu sama-sama merupakan anggota Kongres . Akan halnya nanti dengan anggota Dewan Perwakilan Rakyat dan anggota Dewan Perwakilan Daerah, pada hakikatnya mereka adalah anggota MPR, tetapi secara sendiri-sendiri mereka juga dapat dibedakan antara anggota DPR atau anggota DPD. Demikian pula dalam konstitusi Kerajaan Belanda dikatakan bahwa kekuasaan legislatif berada di 'Staten Generaal' yang terdiri atas "Eerste Kamer en Tweede Kamer”. Keanggotaan dalam masing-masing kamar parlemen Belanda ini tidaklah mengurangi pengertian bahwa pada hakikatnya mereka juga anggota 'Staten Generaal' Lihat Jimly Assidiqie, Perkembangan dan Konsolidasi Lembaga Negara Pasca Reformasi, Jakarta: Setjen dan Kepaniteraan MKRI, cetakan pertama, April 2006, cetakan kedua, Juni 2006, hlm, 203

5 Perubahan yang terakhir dalam rangkaian gelombang reformasi nasional sejak tahun 1998 sampai tahun 2002, adalah perubahan yang ditetapkan dalam Sidang Tahunan MPR tahun 2002. Pengesahan naskah Perubahan 
Banyak pokok-pokok pikiran baru yang diadopsikan ke dalam kerangka UUD NRI Tahun 1945 itu, diantaranya adalah (a) penegasan dianutnya cita demokrasi dan nomokrasi secara sekaligus dan saling melengkapi secara komplamenter; (b) pemisahan kekuasaan dan prinsip "checks and balances' (c) pemurnian

Keempat ditetapkan pada tanggal 10 Agustus 2002. Dalam naskah Perubahan Keempat ini, ditetapkan bahwa (a) Undang-Undang Dasar Negara Republik Indonesia Tahun 1945 sebagaimana telah diubah dengan perubahan pertama, kedua, ketiga, dan perubahan keempat ini adalah Undang-Undang dasar Negara Republik Indonesia Tahun 1945 yang ditetapkan pada tanggal 18 Agustus 1945 dan diberlakukan kembali dengan Dekrit Presiden pada tanggal 5 Juli 1959 serta dikukuhkan secara aklamasi pada tanggal 22 Juli 1959 oleh Dewan Perwakilan Rakyat; (b) Penambahan bagian akhir pada Perubahan Kedua Undang-Undang Dasar Negara Republik Indonesia tahun 1945 dengan kalimat "Perubahan tersebut diputuskan dalam Rapat Paripurna Majelis Permusyawaratan Rakyat Republik Indonesia ke-9 tanggal 18 Agustus 2000 Sidang Tahunan Majelis permusyawaratan Rakyat Republik Indonesia dan mulai berlaku pada tanggal ditetapkan"; (c) pengubahan penomoran Pasal 3 ayat (3) dan ayat (4) Perubahan Ketiga Undang-Undang Dasar Negara Republik Indonesia Tahun 1945 menjadi Pasal 3 ayat (2) dan (3); Pasal 25E Perubahan Kedua Undang-Undang Dasar Negara Republik Indonesia Tahun 1945 menjadi Pasal 25A; (d) penghapusan judul Bab IV tentang Dewan Pertimbangan Agung dan pengubahan substansi Pasal 16 serta penempatannya ke dalam Bab III tentang Kekuasaan Pemerintahan negara; (e) pengubahan dan/atau penambahan Pasal 2 ayat (1); Pasal 6A ayat (4); Pasal 8 ayat (3), Pasal 11 ayat (1); Pasal 16; Pasal 23B; Pasal 23D; Pa-sal 24 ayat (3); Bab XIII, Pasal 31 ayat (1), ayat (2), ayat (3), ayat (4), dan ayat (5); Pasal 32 ayat (1) dan ayat (2); Bab XIV, Pasal 33 ayat (4) dan ayat (5); Pasal 34 ayat (1), ayat (2), ayat (3) dan ayat (4); Pasal 37 ayat (1), ayat (2), ayat (3), ayat (4), dan ayat (5); Aturan Peralihan Pasal I, II, dan III; Aturan Tambahan Pasal I dan II Undang-Undang Dasar Negara Republik Indonesia Tahun 1945. Dengan demikian secara keseluruhan naskah Perubahan Keempat UUD 1945 mencakup 19 pasal, termasuk satu pasal yang dihapus dari naskah UUD. Ke-19 pasal tersebut terdiri atas 31 butir ketentuan yang mengalami perubahan, ditambah 1 butir yang dihapuskan dari naskah UUD. sistem pemerintah presidential; dan (d) penguatan cita persatuan dan keragaman dalam wadah NKRI ${ }^{6}$. Susunan keanggotaan MPR RI berubah secara struktural karena dihapuskannya keberadaan "Utusan Golongan" yang mencerminkan "Prinsip Perwakilan Fungsional" (functional representation) dari unsur keanggotaan MPR RI. Dengan demikian, anggota MPR RI hanya terdiri atas :

1) Anggota DPR RI yang mencerminkan "Prinsip Perwakilan Politik” (political representation); dan

2) Anggota DPD RI yang mencerminkan "Prinsip Perwakilan Daerah" (regional representatif).

Bersamaan dengan perubahan yang bersifat struktural tersebut, fungsi MPR RI juga mengalami perubahan mendasar (perubahan fungsional). Majelis ini tidak lagi berfungsi sebagai "supreme body" yang memiliki kewenangan tertinggi dan tanpa kontrol, dan karena itu kewenangannyapun mengalami perubahan-perubahan mendasar. Sebelum diadakannya perubahan UUD, MPR RI memiliki sejumlah kewenangan yaitu (1) menetapkan Undang-Undang Dasar \& mengubah Undang-Undang Dasar; (2) menetapkan Garis-Garis Besar Haluan Negara; (3) memilih Presiden dan Wakil Presiden; (4) meminta dan menilai pertanggungjawaban Presiden; dan (5) memberhentikan Presiden dan/ atau Wakil Presiden.

Sekarang, setelah diadakannya perubahan UUD NRI Tahun 1945, kewenangan MPR RI berubah menjadi (1) menetapkan Undang-Undang Dasar dan/atau Perubahan UUD; (2) melantik Presiden dan Wakil Presiden; (3) memberhentikan Presiden dan/atau Wakil

6 Jimly Assidiqie, Perkembangan dan Konsolidasi Lembaga Negara Pasca Reformasi, Jakarta: Setjen dan Kepaniteraan MKRI, cetakan pertama, April 2006, cetakan kedua, Juni 2006, h, 203 
Presiden, serta (4) menetapkan Presiden dan/atau Wakil Presiden pengganti sampai terpilihnya Presiden dan/atau Wakil Presiden sebagaimana mestinya.

Diadopsi prinsip pemisahan kekuasaan (separation of power) secara tegas antara fungsi legistatif dan eksekutif dalam perubahan pasal 5 ayat (1) juncto pasal 20 ayat (1) dalam perubahan pertama UUD 1945 yang dipertegas lagi dengan tambahan pasal 20 ayat (5) perubahan kedua UUD $1945^{7}$. Dalam perubahan-perubahan tersebut ditegaskan bahwa kekuasaan membentuk

7 Perubahan Pertama UUD 1945 disahkan dalam Sidang Umum MPR yang diselenggarakan antara tanggal 12 sampai dengan tanggal 19 Oktober 1999. Pengesahan naskah Perubahan Pertama itu tepatnya dilakukan pada tanggal 19 Oktober 1999 yang dapat disebut sebagai tonggak sejarah yang berhasil mematahkan semangat konservatisme dan romantisme di sebagian kalangan masyarakat yang cenderung menyakralkan atau menjadikan UUD 1945 bagaikan sesuatu yang suci dan tidak boleh disentuh oleh ide perubahan sama sekali. Perubahan Pertama ini mencakup perubahan atas 9 pasal UUD 1945, yaitu atas Pasal 5 ayat (1), Pasal 7, Pasal 9 ayat (1) dan ayat (2), Pasal 13 ayat (2) dan ayat (3), Pasal 14 ayat (1) dan ayat (2), Pasal 15, Pasal 17 ayat (2) dan ayat (3), Pasal 20 ayat (1) sampai dengan ayat (4), dan Pasal 21. Kesembilan pasal yang mengalami perubahan atau penambahan tersebut seluruhnya berisi 16 ayat atau dapat disebut ekuivalen dengan 16 butir ketentuan dasar. Setelah tembok romantisme dan sakralisme berhasil dirobohkan, gelombang perubahan atas naskah UUD 1945 terus berlanjut, sehingga dalam Sidang Tahunan pada tahun 2000, MPR menetapkan Perubahan Kedua yaitu pada tanggal 18 Agustus 2000. Cakupan materi yang diubah pada naskah Perubahan Kedua ini lebih luas dan lebih banyak lagi, yaitu mencakup 27 pasal yang tersebar dalam 7 bab, yaitu Bab VI tentang Pemerintah Daerah, Bab VII tentang Dewan Perwakilan Rakyat, Bab IXA tentang Wilayah Negara, Bab $\mathrm{X}$ tentang Warga Negara dan Penduduk, Bab XA tentang Hak Asasi Manusia, Bab XII tentang Pertahanan dan Keamanan Negara, dan Bab XV tentang Bendera, Bahasa, dan Lambang Negara serta Lagu Kebangsaan. Jika ke-27 pasal tersebut dirinci jumlah ayat atau butir ketentuan yang diaturnya, maka isinya mencakup 59 butir ketentuan yang mengalami perubahan atau bertambah dengan rumusan ketentuan baru sama sekali.
Undang-Undang berada di tangan DPR, meskipun Presiden sebagai kepala pemerintahan eksekutif tetap diakui haknya untuk mengajukan sesuatu rancangan Undang-Undang. Dengan perubahan ini berarti UUD 1945 tidak lagi menganut sistem MPR berdasarkan "Prinsip Supremasi Parlemen" dan "Sistem Pembagian Kekuasaan" (distribution of power) oleh lembaga tertinggi MPR ke lembaga-lembaga negara di bawahnya ${ }^{8}$.

Diadopsinya prinsip pemilihan Presiden dan Wakil Presiden dalam satu paket secara langsung oleh rakyat dalam ketentuan pasal 6A ayat (1) perubahan ketiga UUD NRI Tahun 1945 yang sekaligus dimaksud untuk memperkuat dan mempertegas anutan sistem pemerintahan presidential dalam UUD NRI Tahun 1945. Dengan sistem pemilihan langsung oleh rakyat itu, maka konsep dan sistem pertanggung jawaban Presiden tidak lagi dilakukan kepada MPR RI, tetapi juga langsung kepada rakyat. Oleh karena itu, dapat dikatakan bahwa dalam hubungannya dengan pengorganisasian kedaulatan rakyat, kedaulatan yang ada ditangan rakyat itu, sepanjang menyangkut fungsi legislatif, dilakukan oleh MPR RI yang terdiri atas dua kamar dewan, sedangkan dalam bidang eksekutif dilakukan oleh Presiden dan Wakil Presiden sebagai satu paket kepemimpinan eksekutif yang dipilih langsung oleh rakyat ${ }^{9}$.

MPR RI yang dulu dikenal sebagai lembaga tertinggi negara, dimasa depan berubah menjadi nama dari lembaga perwakilan rakyat Indonesia yang terdiri atas DPR RI dan DPD RI yang secara bersama-sama kedudukannya sederajat dengan Presiden dan Wakil Presiden, serta dengan MA dan MK. Namun,

8 Jimly Assidiqie, Struktur Ketatanegaraan Setelah Perubahan Keempat UUD Tahun 1945, Makalah Disampaikan pada Seminar Nasional Pembangunan Hukum Nasional VIII, Denpasar, 14-18 Juli 2003, h, 10-11

9 Ibid 
seperti dikemukakan diatas, lembaga MPR RI pada pokoknya menurut ketentuan UUD NRI Tahun 1945 pasca perubahan Keempat tetap berdiri sendiri di samping DPR RI dan DPD RI. Banyak kritik dan ketidakpuasan mengenai pengaturan UUD NRI Tahun 1945 mengenai hal ini, tetapi dalam kenyataannya memang demikianlah ketentuannya dalam UUD NRI Tahun 1945 pasca Perubahan Keempat.

\section{Pemisahan Kekuasaan Dan Prinsip Checks And Balances}

Prinsip kedaulatan yang berasal dari rakyat tersebut di atas selama ini hanya diwujudkan dalam Majelis Permusyawaratan Rakyat yang merupakan penjelmaan seluruh rakyat, pelaku sepenuhnya kedaulatan rakyat, dan yang diakui sebagai lembaga tertinggi negara dengan kekuasaan yang tidak terbatas. Dari Majelis inilah, kekuasaan rakyat itu dibagi-bagikan secara vertikal ke dalam lembaga-lembaga tinggi negara yang berada dibawahnya. Karena itu, prinsip yang dianut disebut sebagai prinsip pembagian kekuasaan (distribution of power). Akan tetapi, dalam Undan-Undang dasar hasil perubahan, prinsip kedaulatan rakyat tersebut ditentukan dibagikan secara horizontal dengan cara memisahkannya (separation of power) menjadi kekuasaan-kekuasaan yang dinisbatkan sebagai fungsi lembaga-lembaga negara yang sederajat dan saling mengendalikan satu sama lain berdasarkan prinsip 'checks and balaces'.

Cabang kekuasaan legislatif tetap berada di Majelis Permusyawaratan Rakyat, tetapi majelis ini terdiri dari dua lembaga perwakilan yang sederajat dengan lembaga negara lainnya. Untuk melengkapi pelaksanaan tugas-tugas pengawasan, disamping lembaga legislatif dibentuk pula Badan Pemeriksa Keuangan. Cabang kekuasaan eksekutif berada ditangan Presiden dan Wakil
Presiden. Untuk memberikan nasehat dan saran kepada Presiden dan Wakil Presiden, dibentuk pula Dewan Pertimbangan Agung. Sedangkan cabang kekuasaan kehakiman dipegang oleh Mahkamah Agung dan Mahkamah Konstitusi. Majelis Permusyawaratan Rakyat tetap merupakan rumah penjelmaan seluruh rakyat yang strukturnya dikembangkan dalam dua kamar, yaitu Dewan Perwakilan Rakyat dan Dewan Perwakilan Rakyat Daerah. Oleh karena itu, prinsip perwakilan daerah dalam Dewan Perwakilan Rakyat Daerah harus dibedakan hakikatnya dari prinsip perwakilan rakyat dalam Dewan Perwakilan Rakyat. Maksudnya ialah agar seluruh aspirasi rakyat benar-benar dapat dijelmakan ke dalam Majelis Perusyawaratan Rakyat yang terdiri dari dua pintu.

Kedudukan MPR yang terdiri dari dua lembaga perwakilan itu itu adalah sederajad dengan Presiden dan Mahkamah Agung dan Mahkamah Konstitusi. Ketiga cabang kekuasaan legislatif, eksekutif, dan yudikatif itu sama-sama sederajat dan saling mengontrol satu sama lain sesuai dengan prinsip 'Check and balances'. Dengan adanya prinsip 'Check and balances' ini, maka kekuasaan negara dapat diatur, dibatasi dan bahkan dikontrol dengan sesebaik-baiknya, sehingga penyalahgunaan kekuasaan oleh aparat penyelenggara negara ataupun pribadi-pribadi yang kebetulan sedang menduduki jabatan dalam lembaga-lembaga negara yang bersangkutan dapat dicegah dan ditanggulangi dengan sebaik-baiknya, Pasal-pasal yang dapat dianggap mencerminkan perubahan tersebut antara lain adalah perubahan ketentuan pasal 5, terutama ayat (1) juncto pasal 20 ayat (1) sampai dengan ayat (5) yang secara jelas menentukan bahwa fungsi legislatif ada pada Dewan Perwakilan Rakyat, sedangkan Presiden adalah kepala eksekutif. Disamping itu, ada pula 
ketentuan mengenai kewenangan MPR yang tidak lagi dijadikan tempat kemana presiden harus bertanggungjawab atau menyampaikan pertanggung-jawaban jabatannya.

Selain itu, ketentuan mengenai Mahkamah Konstitusi yang diberi kewenangan untuk melakukan pengujian atas Undang-Undang terhadap Undang-Undang Dasar seperti ditentukan dalam Pasal 24 ayat (1) juga mencerminkan dianutnya asas pemisahan kekuasaan dan prinsip 'check and balances' antara cabang kekuasaan legislatif dan yudikatif. Ketiga ketentuan itu memastikan tafsir berkenaan dengan terjadinya pergeseran MPR dari kedudukannya sebagai lembaga tertinggi menjadi lembaga yang sederajat dengan Presiden berdasarkan pemisahan kekuasaan dan prinsip 'check and balances'.

\section{Penguatan Asas Kedaulatan Rakyat}

Negara Indonesia menganut paham kedaulatan rakyat atau democratie (democracy). Pemilik kekuasaan tertinggi dalam negara adalah rakyat. Kekuasaan yang sesungguhnya adalah berasal dari rakyat, oleh rakyat, dan untuk rakyat. Kekuasaan bahkan diidealkan diselenggarakan bersama-sama dengan rakyat. Dalam sistem konstitusional Undang-Undang Dasar, pelaksanaannya kedaulatan rakyat itu disalurkan dan diselenggarakan menurut prosedur konstitusional yang ditetapkan dalam hukum dan konstitusi (constitutional democracy). Prinsip kedaulatan rakyat (democratie) dan kedaulatan hukum (nomocratie) hendaklah diselenggarakan secara beriringan sebagai dua sisi dari mata uang yang sama. UUD NRI Tahun 1945 menegaskan bahwa Negara Republik Indonesia itu adalah Negara Hukum yang demokrasi (democratische rechtstaat) dan sekaligus adalah Negara Demokrasi yang berdasarkan atau hukum (constitutional democracy) yang tidak terpisahkan satu sama lain.

Kedaulatan rakyat (democratie) Indonesia itu diselenggarakan secara langsung dan melalui sistem perwakilan. Secara langsung, kedaulatan rakyat itu diwujudkan dalam tiga cabang kekuasaan yang tercermin dalam MPR RI yang terdiri dari DPR RI dan DPD RI; presiden dan wakil presiden ; dan kekuasaan Kehakiman yang terdiri atas MK dan MA Dalam menetukan kebijakan pokok pemerintahan dan mengatur ketentuan-ketentuan hukum berupa UUD dan UU (fungsi Legislatif), serta dalam menjalankan fungsi pengawasan (fungsi kontrol) terhadap jalannya pemerintahan, pelembagaan kedaulatan rakyat itu disalurkan melalui sistem perwakilan, yaitu melalui MPR RI, DPR RI dan DPD RI. Di daerah-daerah propinsi dan kabupaten / kota, pelembagaan kedaulatan rakyat itu juga disalurkan melalui sistem perwakilan, yaitu melalui Dewan Perwakilan Rakyat Daerah (DPRD). Penyaluran kedaulatan rakyat secara langsung (direct democracy) dilakukan melalui pemilihan umum untuk memlih anggota lembaga perwakilan dan memilih Presiden dan Wakil presiden. Disamping itu, kedaulatan rakyat dapat pula disalurkan setipa waktu melalui pelaksanaan hak dan kebebasan berpendapat, hak atas kebebasan pers, hak atas kebebasan informasi, kebebasan pers, hak atas kebebasan berorganisasi dan berserikat serta hakhak asasi lainnya yang dijamin dalam UUD. Namun, prinsip kedaulatan rakyat yang bersifat langsung itu hendaklah dilakukan melalui saluran-saluran yang sah sesuai dengan prosedur demokrasi (procedural democracy). Sudah seharusnya lembaga perwakilan rakyat dan lembaga perwakilan daerah diberdayakan fungsinya dan pelembagaannya, sehingga dapat memperkuat sistem demokrasi yang berdasar atas hukum (demokrasi Konstitusional) dan prinsip negara hukum yang demokratis tersebut di atas. Bersamaan dengan itu, negara Indonesia 
juga disebut sebagai Negara Hukum (Rechtstaat), bukan Negara Kekuasaan (Machtstaat). Di dalamnya terkandung pengertian adanya pengakuan terhadap prinsip supremasi hukum dan konstitusi, dianutnya prinsip pemisahan dan pembatasan kekuasaan menurut sistem konstitusional yang diatur dalam Undang-Undang Dasar, adanya jaminan-jaminan hak asasi manusia dalam Undang-Undang dasar, adanya prinsip peradilan yang bebas dan tidak memihak yang menjamin persamaan setiap warga negara dalam hukum, serta menjamin keadilan bagi orang termasuk terhadap penyalahgunaan wewenang oleh pihak yang berkuasa.

Dalam paham Negara Hukum yang demikian itu, pada hakikatnya hukum itu sendirilah yang menjadi penentu segalanya sesuai dengan prinsip nomokrasi (nomcrasy) dan doktrin 'the Rule of Law, and not of Man'. Dalam kerangka 'the rule of Law' itu, diyakini adanya pengakuan bahwa hukum itu mempunyai kedudukan tertinggi (supremelacy of law), adanya persamaan dalam hukum dan pemerintah (equality before the law), dan berlakunya asas legalitas dalam segala bentuknya dalam kenyataan praktek (due process of law). Namun demikian, harus pula ada jaminan bahwa hukum itu sendiri dibangun dan ditegakkan menurut prinsip-prinsip demokrasi. Karena prinsip supremasi hukum dan kedaulatan hukum itu sendiri pada pokoknya berasal dari kedaulatan rakyat. Oleh sebab itu, prinsip negara hukum hendaklah dibangun dan dikembangkan menurut prinsip-prinsip demokrasi atau kedaulatan rakyat (democratische rechtsstaat). Hukum tidak boleh dibuat, ditetapkan, ditafsirkan dan ditegakkan dengan tangan besi berdasarkan kekuasaan belaka (Machtstaat). Prinsip Negara Hukum tidak boleh ditegakkan dengan mengabaikan prinsip-prinsip demokrasi yang diatur dalam UUD. Puncak kekuasaan hukum itu diletakkan pada konstitusi yang pada hakikatnya merupakan dokumen kesepakatan tentang sistem kenegaraan tertinggi. Bahkan, dalam sistem presidensil yang dikembangkan, konstitusi itulah yang pada hakikatnya merupakan Kepala Negara Republik Indonesia yang bersifat simbolik (symbolic head of state), dengan keberadaan MK sebagai penyangga atau 'the guardian of the Indonesian constitution'.

Ketentuan mengenai cita-cita negara hukum ini secara tegas dirumuskan dalam pasal 1 ayat (3) UUD NRI Tahun 1945, yang menyatakan: 'Negara Indonesia adalah Negara Hukum', sebelum ini, rumusan naskah asli UUD 1945 tidak mencantumkan ketentuan mengenai negara hukum ini, kecuali hanya dalam penjelasan UUD NRI Tahun 1945 yang menggunakan istilah 'rechtsstaat'. Rumusan eksplisit bahwa Indonesia adalah negara hukum baru terdapat dalam Konstitusi Republik Indonesia Serikat tahun 1949 dan UUD Sementara Tahun 1950. Untuk mengatasi kekuarangan itulah maka dalam perubahan ketiga UUD NRI Tahun $1945^{10}$, ide negara hukum (rechtstaat

10 Dalam Sidang Tahunan MPR tahun 2001 yang berhasil menetapkan naskah Perubahan Ketiga UUD 1945 pada tanggal 9 November 2001. Bab-bab UUD 1945 yang mengalami perubahan dalam naskah Perubahan Ketiga ini adalah Bab I tentang Bentuk dan Kedaulatan, Bab II tentang Majelis Permusyawaratan Rakyat, Bab III tentang Kekuasaan Pemerintahan Negara, Bab $\mathrm{V}$ tentang Kementerian Negara, Bab VIIA tentang Dewan Perwakilan Daerah, Bab VIIB tentang Pemilihan Umum, dan Bab VIIIA tentang Badan Pemeriksa Keuangan. Seluruhnya terdiri atas 7 bab, 23 pasal, dan 68 butir ketentuan atau ayat. Dari segi jumlahnya dapat dikatakan naskah Perubahan Ketiga ini memang paling luas cakupan materinya. Tapi di samping itu, substansi yang diaturnya juga sebagian besar sangat mendasar. Materi yang tergolong sukar mendapat kesepakatan cenderung ditunda pembahasannya dalam sidang-sidang terdahulu. Karena itu, selain secara kuantitatif materi Perubahan Ketiga ini lebih banyak muatannya, juga dari segi isinya, secara kualitatif materi Perubahan Ketiga ini dapat dikatakan sangat mendasar pula. 
atau the rule of law) itu diadopsikan secara tegas ke dalam rumusan pasal UUD NRI Tahun 1945, yaitu pasal 1 ayat (3) tersebut diatas. Sementara itu, ketentuan mengenai prinsip kedaulatan rakyat terdapat dalam pembukaan dan juga pada pasal 1 ayat (2). Cita-cita kedaulatan tergambar dalam pembukaan UUD NRI Tahun 1945, terutama dalam rumusan alinea IV tentang dasar negara yang kemudian dikenal dengan sebutan Pancasila. Dalam alinea ini, cita-cita kerakyatan dirumuskan secara jelas sebagai "Kerakyatan yang dipimpin oleh hikmah kebijaksanaan dalam permusyawaratan/ perwakilan". Sedangkan dalam rumusan pasal 1 ayat (2), semangat kerakyatan itu ditegaskan dalam ketentuan yang menegaskan bahwa "kedaulatan berada di tangan rakyat dan dilaksanakan menurut Undang-Undang Dasar".

Garis-Garis Besar Haluan Negara (GBHN) yang semula ditetapkan oleh MPR RI berfungsi sebagai landasan perencanaan pembangunan Nasional sebagaimana telah dilaksanakan dalam praktek ketatanegaraan selama ini. Ketetapan MPR RI ini menjadi landasan hukum bagi Presiden untuk dijabarkan dalam bentuk Rencana Pembangunan Lima Tahunan dengan memperhatikan secara sungguh-sungguh saran DPR RI, yang selanjutnya Pemerintah bersama DPR RI menyusun APBN. Perubahan UUD NRI Tahun 1945 yang mengatur bahwa Presiden dipilih secara langsung oleh rakyat dan tidak adanya GBHN sebagai pedoman Presiden untuk menyusun rencana pembangunan maka dibutuhkan pengaturan lebih lanjut bagi proses perencanaan pembangunan Nasional, yang didasarkan pada kerangka pemikiran bahwa: ${ }^{11}$

1) atas berkat rahmat Allah Yang Maha Kuasa, Proklamasi Kemerdekaan telah mengantarkan

11 Perhatikan dictum "menimbang UU Nomor 25 Tahun 2004 Tentang Sistim Perencanaan Pembangunan Nasional bangsa Indonesia menuju cita-cita berkehidupan kebangsaan yang bebas, bersatu, berdaulat, adil, dan makmur;

2) pemerintahan negara Indonesia dibentuk untuk melindungi segenap bangsa Indonesia dan seluruh tumpah darah Indonesia, memajukan kesejahteraan umum, mencerdaskan kehidupan bangsa, dan ikut melaksanakan ketertiban dunia;

3) tugas pokok bangsa selanjutnya adalah menyempurnakan dan menjaga kemerdekaan itu serta mengisinya dengan pembangunan yang berkeadilan dan demokratis yang dilaksanakan secara bertahap dan berkesinambungan;

4) untuk menjamin agar kegiatan pembangunan berjalan efektif, efisien, dan bersasaran maka diperlukan perencanaan pembangunan Nasional;

Namun demikian ketika kurang dari 15 Tahun sistem ini berjalan tanpa hadirnya GBHN sebagai otoritas tertinggi yang mengarahkan pembangunan bangsa, tidak dapat dipungkiri bahwa Rencana Pembangan Jangka Panjang Nasional (RPJPN) yang disusun dan dilaksanakan selama ini belum sepenuhnya menjawab secara komprehensif permasalahan kebangsaan yang dihadapi Indonesia dewasa ini.

Sistim presidnsial yang selama ini dilaksanakan belum sepenuhnya terlepas dari tirani kekuasaan partai politik, sehingga banyak terjadi benturan kepentingan antara kekuasaan legislatif (parlamen) dengan Presiden dalam menjalankan kekuasaan pemerintahan. Hal ini dapat dilihat dari konstruksi pergeseran kekuasaan itu terlihat jelas kala dilacak keberadaan pasal-pasal dalam konstitusi yang berkaitan dengan pengisian pimpinan sejumlah lembaga negara. Misalkan, Pasal 13 Ayat (2) UUD 1945 meny atakan, dalam hal 
mengangkat duta, presiden mempertimbangkan pertimbangan DPR. Begitu pula, dalam pengisian anggota Badan Pemeriksa Keuangan (BPK), Pasal 23F Ayat (1) UUD 1945 menyatakan, anggota BPK dipilih oleh DPR dengan memperhatikan pertimbangan DPD. Pada perkembanganya, kuasa DPR atas pengisian pimpinan lembaga negara semakin melebarkan sayapnya hingga komisi-komisi yang hakikat pendirianya bersifat independen. Misalkan, Pasal 30 UU No. 30 Tahun 2002 Tentang Komisi Pemberantasan Tindak Pidana Korupsi menyatakan, DPR memilih dan menetapkan pimpinan KPK yang diusulkan oleh panitia seleksi bentukan presiden. Begitu pula dalam pengisian anggota Komnas HAM yang juga dipilih oleh DPR. Tak jauh berbeda, anggota Komisi Pemilihan Umum (KPU) pun juga di pilih melalui proses fit and proper test di DPR, ini sesuai dengan amanat Pasal 15 ayat (2) UU No. 15 Tahun 2011 Tentang Penyelenggara Pemilu. Di kondisi yang lebih ekstrim, pengisian jabatan lembaga negara di bawahdomainya eksekutif juga membutuhkan persetujuan DPR. Sebut saja pemilihan Kapolri dan Panglima TNI. Bahkan, berdasarkan Pasal 11 ayat (1) UU No. 2 Tahun 2002 Tentang Kepolisian, untuk pengangkatan dan pemberhentian Kapolri harus melalui persetujuan DPR. Problem yang tak jauh berbeda juga terjadi pada pengisian jabatan di lembaga dan institusi negara lain seperti Pimpinan Bank Indonesia, Otoritas Jasa Keuangan, Lembaga Penjamin Simpanan, Ombudsman, Komisi Kepolisian, Komisi Kejaksaan, Badan Pengawas Pemilu, dan lain-lain sebagainya.

Dalam paradigma positivism ketatanegaraan dalam hubungannya dengan menjamin tegaknya konstitusionalisme pada umumnya bersandar pada tiga unsur kesepakatan, yaitu: (i) the general goals of society or general acceptance of the same philosophy of government (kesepakatan tentang tujuan atau cita-cita bersama tentang pemerintahan); (ii) the rule of law or the basis of government (kesepakatan tentang negara hukum sebagai landasan pemerintahan atau penyelenggara negara); (iii) the form of institutions and procedures (kesepakatan tentang bentuk institusi-institusi dan prosedur-prosedur ketatanegaraan), dalam realitasnya tidak banyak diwujudkan secara konsisten dan progresif oleh pemerintah meskipun ruang-ruang transisi politik demokrasi lebih terbuka, perubahan konstitusi dan reformasi hukum dalam sejumlah hal lebih baik dibandingkan sebelumnya. Termasuk mempertanyakan mengapa perlindungan hak-hak konstitusional yang sudah menjadi 82 andate negara, utamanya pemerintah.

\section{PE N T U P}

Dinamika dan perkembangan ketatanegaraan Indonesia pasca amandemen UUD NRI Tahun 1945, perlu kembali diberikan penguatan khususnya terhadap eksistensi terhadap pelaskanaan prinsip kedaulatan rakyat sebagaimana dimaksud dalam ketentuan Pasal 1 ayat (2) UUD 1945 dalam implementasinya akan menimbulkan permasalahan mengenai ukuran konstitusionalitas dari pelaksanaan kedaulatan rakyat menurut UUD.

Mereformulasikan kembali gagasan konstitusional tentang pelaksanaan asas kedaulatan rakyat melalui perumusan GBHN tidaklah dimaknai sebagai pelemahan terhadap esensi tentang check and balances dan prinsip pemisahan kekuasaan (separation of power) secara tegas antara fungsi legistatif dan eksekutif dalam perubahan pasal 5 ayat (1) juncto pasal 20 ayat (1) dalam perubahan pertama UUD NRI Tahun 1945 yang dipertegas lagi dengan tambahan pasal 20 ayat (5) perubahan kedua UUD NRI Tahun 1945. Pengaturan yang demikian hanya dapat dilakukan 
melalui amandemen UUD NRI Tahun 1945;

\section{DAFTAR PUSTAKA}

Ellydar Chaidir, Teori Konstitusi Dalam Prespektif Hukum Kritis,Total Media, Yogyakarta, 2007,

Jimly Assidiqie, Konstitusi \& Konstitusionalisme Indonesia. Edisi Revisi. Jakarta: Konstitusi Press, 2005 .

Rakyat dalam Konstitusi dan
Pelaksanaannya di Indonesia.
Jakarta, 2005
konstitusi
$\begin{gathered}\text { Gagasan dan } \\ \text { dan }\end{gathered}$
Konstitusi, 2007

Konsolidasi Lembaga Negara
Pasca Reformasi, Jakarta: Setjen
dan Kepaniteraan MKRI, cetakan
pertama, April 2006, cetakan
kedua, Juni 2006,
Perkembangan dan
Konsolidasi Lembaga Negara
Pasca Reformasi, Jakarta: Setjen
dan Kepaniteraan MKRI, cetakan
pertama, April 2006, cetakan
kedua, Juni 2006,
, Struktur Ketatanegaraan
Setelah Perubahan Keempat UUD
Tahun 1945, Makalah Disampaikan
pada Seminar Nasional
Pembangunan Hukum Nasional
VIII, Denpasar, 14-18 Juli 2003,
William G. Andrews Constitutions and
Constitutionalism, 3rd edition, New
Jersey: Van Nostrand Company,
1968

